\title{
EFFECT OF INCORPORATING WHEY PROTEIN HYDROLYSATE ON PROCESSED CHEESE SPREAD QUALITY
}

\author{
Kh.M.K. Kebary, R.M. Badawi, K.M. Kamaly and A.A.M. Shaheen \\ Depart. of Dairy sci. and Technology, Fac. of Agriculture, Menofia university, Shebin El-Kom. \\ Received: Mar. 7, 2018 \\ Accepted: Mar. 11, 2018
}

\begin{abstract}
Five processed cheese spread treatments were made to investigate the effect of incorporating whey protein hydrolysate on the quality attributes of resultant processed cheese spread. Whey protein hydrolysate was incorporated at the rate of 2.5, 5.0, 7.5 and $10 \%$ instead of fresh Ras cheese that used to making control processed cheese spread. The resultant processed cheese treatments were stored for 3 months at 6 $\pm 2 C^{\circ}$. The obtained results revealed that incorporation of whey protein hydrolysate caused a slight increase in $\mathrm{pH}$ values, total protein, soluble protein contents and meltability of cheese, while caused a significant reduction in oil separation index, ash content and titratable acidity changes were proportional to the rate of whey protein hydrolysate substitution. Incorporation of whey protein hydrolysate decreased the whiteness of processed cheese spread treatments, while increased the values of $a, b$ and $\Delta E$ (change in colour). Adding whey protein hydrolysate increased hardness, adhesiveness, cohesiveness and springiness of the resulting processed cheese spread treatments, while decreased the values of gumminess and chewiness. Incorporating whey protein hydrolysate up to $5.0 \%$ did not affect significantly the acceptability and organoleptic scores, while increasing the ratio of adding whey protein hydrolysate above $5.0 \%$ caused a significant decrease in the organoleptic scores of resultant processed cheese spread. Titratable acidity, total protein content and oil separation of processed cheese spread treatments were slightly increased during storage period, while $\mathrm{pH}$ values, meltability and moisture content decreased.
\end{abstract}

Key words: Whey protein hydrolysate, processed cheese spread, oil separation, meltability.

\section{INTRODUCTION}

The production of processed cheese and processed cheese spread have been increased markedly in Egypt and over all the world because of applying modern technology and equipment which enables the manufactures to produce different types and forms of processed cheese using a wide range of ingredients and flavours (Business wire, 2017). Processed cheese is particularly popular in Egypt: in 2016 it represented a quarter of the total cheese imports of 115,000 tons (IDF 2016). Processed cheese is used in many different ways - as a slice in a toasted sandwich or burger, shredded on pizzas, in Cordon Bleu type products, as a spread on bread, as a dip for snacks, or even for cheese sauces, or as an ingredient for ready meals (Arla Foods Ingredients Bulletin, 2016).

Whey protein (WP) is considered a high quality protein since it is rich in all essential amino acids, and has a biological value that is $15 \%$ greater than the benchmark egg protein. In addition to its high nutritional quality, whey protein has been recognized for several physiological functions, such as antimicrobial activity, growth promotional activity and immunoactivity, attributed to the naturally occurring lactoferrin, growth factors and immunoglobulin peptides, respectively (Kitts and Weiler, 2003 and Smithers, 
2008). Whey protein help to improve the blood level of glutathione; an antioxidant essential for a healthy immune system. Whey protein gained popularity not only for its nutritional and biological value but also for its unique physicochemical characteristics, which allow it to have versatile functionality, such as gelation, foaming and emulsification (Foegeding et al., 2002). Whey protein has great solubility under acidic conditions (Pelegrine and Gasparetto, 2005), which make it the protein of choice for proteinfortified acidic beverages.

Whey protein hydrolysate (WPH) considered to be the purest form of proteins and could be better soluble, thermostable, and resistant to coalescence and they could have better emulsifying and foaming activity (Perez et al., 2012). Moreover, the enzyme hydrolysis could generate some biologically active peptides, for example with ACE inhibitory, antihypertension or prebiotic function (Pan et al., 2012 and Wang et al., 2012). For these reasons WPH is a worthwhile functional food ingredient. However, its usability in the food industry is limited by a bitter taste, which is probably linked with the generation of hydrophobic peptides (Welderufael et al., 2012). WPH increased digestibility of small peptides compared to whole proteins, which has been found to be especially beneficial for patients suffering from digestion disorders, such as cystic fibrosis, short bowel syndrome or pancreatitis (Rees et al., 1992; Frokjaer, 1994; Schmidl et al., 1994).

In view of the aforementioned the objectives of this study were to investigate the possibility of improving the nutritional and quality attributes of processed cheese by using whey protein hydrolysate and to monitor the changes of processed cheese spread quality during storage period.

\section{MATERIALS AND METHODS Ingredients:}

Egyptian fresh and 1.5 months old Ras cheese were purchased from the local market at Shebin El-Kom, Menoufia, Egypt. Commercial skim milk powder (SMP) made in Egypt by Dina farms was used. Commercial New Zealand butter was purchased from the local market at Shebin El-Kom, Menoufia, Egypt. Whey protein hydrolysate was obtained from Arla Foods Ingredients, Skanderbrogvey, Denmark. Emulsifying salt was obtained from Fibrisol the Vital Ingredient, Sunmore Close, Heatherton, Australia.

\section{Cheese making:}

The basic blend of processed cheese spread was planned to contain $42 \%$ dry matter and $45 \%$ Fat/Dry matter according to Egyptian Orgnization for Standards (2013) using fresh Ras cheese, 1.5 month old Ras cheese, skim milk powder, butter, emulsifying salt, whey protein hydrolysate (Table 1) T1, T2, T3 and T4 were prepared by incorporating 2.5, 5.0, 7.5 and $10 \%$ of whey protein hydrolysate as a substitution of fresh Ras cheese, respectively. The preparation of the ingredients and cooking procedure were carried out as described by Mayer (1973) at $85^{\circ} \mathrm{C}$ for $8 \mathrm{~min}$. using a double jacket pan with a bath capacity $1.25 \mathrm{~kg}$ and stirring velocity of $60-80$ r.p.m. Thereafter, the resultant spreads were packed in airtight closed glass jars (125 g), and stored at $6 \pm 2^{\circ} \mathrm{C}$ for 3 months.

\section{Chemical analysis:}

Fat content was determined using the Gerber method as described by Ling (1963). Moisture, Total protein, soluble nitrogen, ash content and acidity were determined according to A.O.A.C. (2010). $\mathrm{pH}$ value was determined using a digital pH meter (model HANNA) equipped with Plastic electrode. 
Table (1). The blend formulas $(\mathrm{kg} / 100 \mathrm{~kg})$ of processed cheese spread with adding whey protein hydrolysate.

\begin{tabular}{||l|c|c|c|c|c|}
\hline \multirow{2}{*}{\multicolumn{1}{|c|}{ Ingredients }} & \multicolumn{5}{c|}{ Treatments $^{*}$} \\
\cline { 2 - 6 } & $\mathrm{C}$ & $\mathrm{T}_{1}$ & $\mathrm{~T}_{2}$ & $\mathrm{~T}_{3}$ & $\mathrm{~T}_{4}$ \\
\hline Ras cheese (1.5 month old) & 10 & 10 & 10 & 10 & 10 \\
Ras cheese (fresh) & 34 & 25.9 & 19.85 & 13.9 & 7.9 \\
Skim milk powder & 2.5 & 2.5 & 2.5 & 2.5 & 2.5 \\
Emulsifying salt & 2.5 & 2.5 & 2.5 & 2.5 & 2.5 \\
Butter & 10.33 & 12.54 & 13.56 & 14.52 & 15.51 \\
Whey protein hydrolysate & - & 2.5 & 5 & 7.5 & 10 \\
Water & 40.67 & 44.06 & 46.59 & 49.08 & 51.59 \\
\hline Total & 100 & 100 & 100 & 100 & 100 \\
\hline
\end{tabular}

${ }^{*} \mathrm{C}$ : control processed cheese spread; $\mathrm{T}_{1}, \mathrm{~T}_{2}, \mathrm{~T}_{3}$ and $\mathrm{T}_{4}$ processed cheese spread treatments made by incorporating $2.5,5,7.5$ and $10 \%$ of whey protein hydrolysate

\section{Physical analysis:}

Colour was measured as mentioned by Trierum, (2002) using a Hunter-Lab optical sensor (0/45 D 25 - PC 2, Hunter Associates Laboratory Inc., Reston, VA, USA). Oil separation of processed cheese spreads was determined according to the method of Thomas (1973). Meltability of processed cheese was determined according to Olson and Price (1958) and modified by Rayan et al. (1980). Textural properties of cheese were evaluated as described by Bonczar et al., (2002) using a texture analyzer (TA1000, Lab Pro (FTC TMS-Pro), Food Technology Corporation, USA).

\section{Sensory evaluation:}

Cheese sample were evaluated for flavour (out of 45 points), body and texture (out of 35 points), appearance (out of 10 points) and colour (out of 10 points) as described by Kebary et al. (2001) by 10 panelists from the staff at the Department of Dairy Science and Technology, and Department of Food
Science and Technology, Faculty of Agriculture, Menoufia University, Shebin El-Kom, Egypt.

\section{Statistical analysis:}

Data were analyzed using the completely randomized block design and $2 \times 3$ factorial design. Newman-Keuls, test was used to make the multiple comparisons (Steel and Torrie, 1980) using CoStat Software program, Version 6.4 (2008). Significant differences were determined at $p \leq 0.05$.

\section{RESULTS AND DISCUSSION}

Acidity values of all processed cheese spread treatments increased slightly ( $p \leq$ 0.05 ) during storage of processed cheese spread (Table 2). In addition, acidity of processed cheese spread treatments decreased slightly ( $p \leq 0.05$ ) by adding WPH and this decrease was proportional to the rate of replacement. These results are in agreement with those reported by Guinee et al. (2004) and Lee et al. (2009). 
Kh.M.K. Kebary, et al.,

Table (2). Effect of incorporating whey protein hydrolysate on Acidity (\%) and pH value of processed cheese spread.

\begin{tabular}{|c|c|c|c|c|c|c|c|c||}
\hline \multirow{3}{*}{ Treatments $^{*}$} & \multicolumn{3}{|c|}{ Titratable acidity (\%) } & \multicolumn{4}{c||}{ pH values } \\
\cline { 2 - 8 } & \multicolumn{3}{|c|}{ Storage period (Months) } & \multicolumn{3}{c||}{ Storage period (Months) } \\
\cline { 2 - 8 } & 0 & 1 & 2 & 3 & 0 & 1 & 2 & 3 \\
\hline $\mathrm{C}$ & $1.39^{\mathrm{Ab}}$ & $1.42^{\mathrm{Aab}}$ & $1.45^{\mathrm{Aa}}$ & $1.48^{\mathrm{Aa}}$ & $5.71^{\mathrm{Ca}}$ & $5.68^{\mathrm{Ca}}$ & $5.66^{\mathrm{Cab}}$ & $5.63^{\mathrm{Cb}}$ \\
$\mathrm{T}_{1}$ & $1.36^{\mathrm{Ab}}$ & $1.39^{\mathrm{Aab}}$ & $1.41^{\mathrm{Aa}}$ & $1.44^{\mathrm{Aa}}$ & $5.76^{\mathrm{BCa}}$ & $5.74^{\mathrm{BCa}}$ & $5.71^{\mathrm{BCab}}$ & $5.69^{\mathrm{BCb}}$ \\
$\mathrm{T}_{2}$ & $1.33^{\mathrm{Ab}}$ & $1.35^{\mathrm{Aab}}$ & $1.38^{\mathrm{Aa}}$ & $1.40^{\mathrm{Aa}}$ & $5.80^{\mathrm{ABa}}$ & $5.78^{\mathrm{ABa}}$ & $5.75^{\mathrm{ABab}}$ & $5.73^{\mathrm{ABb}}$ \\
$\mathrm{T}_{3}$ & $1.29^{\mathrm{ABb}}$ & $1.31^{\mathrm{ABab}}$ & $1.33^{\mathrm{ABa}}$ & $1.36^{\mathrm{ABa}}$ & $5.86^{\mathrm{Aa}}$ & $5.83^{\mathrm{Aa}}$ & $5.81^{\mathrm{Aab}}$ & $5.79^{\mathrm{Ab}}$ \\
$\mathrm{T}_{4}$ & $1.27^{\mathrm{Bb}}$ & $1.29^{\mathrm{Bab}}$ & $1.31^{\mathrm{Ba}}$ & $1.34^{\mathrm{Ba}}$ & $5.95^{\mathrm{Aa}}$ & $5.92^{\mathrm{Aa}}$ & $5.90^{\mathrm{Aab}}$ & $5.87^{\mathrm{Ab}}$ \\
\hline
\end{tabular}

${ }^{*} \mathrm{C}$ : control processed cheese spread; $T_{1}, T_{2}, T_{3}$ and $T_{4}$ processed cheese spread treatments made by incorporating $2.5,5,7.5$ and

$10 \%$ of whey protein hydrolysate.

Different capital letters in the same column means the treatments are different. Significant at 0.05 level $(P \leq 0.05)$.

Different small letters in the same row means the treatments are different during storage period. Significant at 0.05 level $(P \leq 0.05)$.

$\mathrm{pH}$ values of all processed cheese spread treatments decreased slightly $(p \leq$ 0.05 ) during storage of processed cheese spread (Table 2). pH values of processed cheese spread treatments increased significantly $(p \leq 0.05)$ and this increase was proportional to the rate of replacement. These results are in agreement with those reported by Abd ElSalam et al. (1996), El-Shibiny et al. (1996) and Kebary et al. (1998).

Moisture content of all processed cheese spread treatments decreased slightly $(p \leq 0.05)$ during storage of processed cheese spread due to evaporation of cheese moisture (Table 3). On the other hand, incorporating whey protein hydrolysate did not affect significantly $(p>0.05)$ the moisture content of processed cheese spread treatments. These results are in agreement with those reported by AlKhamy et al. (1997), Hussein et al. (1999),
Kebary et al. (1998) and Kebary et al. (2001).

Fat content of all processed cheese spread treatments did not change significantly $(p>0.05)$ during storage of processed cheese spread (Table 3). There were no significant $(p>0.05)$ differences among processed cheese spread treatments, which means incorporating of whey protein hydrolysate did not affect significantly ( $p$ $>0.05$ ) the fat content of the resultant processed cheese spread. These results are in agreement with those reported by Pinto et al. (2007), Mihulova et al. (2013) and Solowiej et al. (2015).

Total protein content of all processed cheese spread treatments increased slightly $(p \leq 0.05)$ during storage of processed cheese spread (Table 3 ). This increase might be due to the loss of moisture content during storage. Incorporating whey protein hydrolysate caused a significant $(p \leq 0.05)$ increase in 
total protein content of processed cheese spread treatments and this increase was proportional to the rate of replacement. This increase might be due to the higher protein content of whey protein hydrolysate than that of fresh Ras cheese. These results are in agreement with those reported by Kebary et al. (1998), Pinto et al. (2007), Mihulova et al. (2013) and Solowiej et al. (2015).

Soluble protein content of all processed cheese spread treatments did not change significantly $(p>0.05)$ throughout storage period of processed cheese spread (Table 4). Soluble protein content of processed cheese spread treatments increased slightly ( $p \leq 0.05$ ) with replacing WPH instead of Ras cheese and this increase was proportional to the rate of replacement Similar results were reported by AbdelBaky et al. (1987), Gouda and Elshiliny (1987), Kebary et al. (1998) and Pinto et al. (2007).

Ash content of all processed cheese spread treatments did not change significantly $(p>0.05)$ during storage of processed cheese spread (Table 4). Ash content of processed cheese spread treatments decreased slightly ( $p \leq 0.05$ ) and this decrease was proportional to the rate of replacement. Similar results were reported by Hussein et al. (1999) and Kebary et al. (2001).

Oil separation of all processed cheese spread treatments increased significantly ( $p \leq 0.05)$ as storage period progressed (Table 4). Oil separation of processed cheese spread treatments decreased significantly ( $p \leq 0.05$ ) by adding WPH in the blend and this decrease was proportional to the rate of replacement which might be due to the increase of emulsifying ability by adding protein. These results are in accordance with those reported by Hamed et al. (1997), Kebary et al. (1998), Hussein et al. (1999) and Badawi et al. (2001).
Meltability of all processed cheese spread treatments decreased significantly ( $p \leq 0.05$ ) as storage period advanced (Table 5). Incorporation of whey protein hydrolysate in processed cheese spread caused a significant ( $p \leq$ 0.05 ) increase in meltability of resultant processed cheese spread treatments. This increase was proportional to the rate of replacement. These results are in accordance with those reported by Kebary et al. (1998), Hussein et al. (1999), Badawi et al. (2001) and Solowiej et al. (2012).

Incorporating whey protein hydrolysate caused a significant decrease $(p \leq 0.05)$ in whiteness of processed cheese spread treatments (Table 5). There were negative correlation between the value of lightness and the rate of incorporating whey protein hydrolysate. On the other hand, a, b and $\Delta E$ values increased by increasing the rate of incorporating whey protein hydrolysate (Table 5). All processed cheese spread treatments contained whey protein hydrolysate particularly at higher amount of incorporation exhibited a white yellowish colour. These results might be due to Maillard reaction. Whey proteins contain a high amount of the amino acid lysine which is typically the most reactive amino acid in regard to the Maillard reaction (Trierum, 2002 and Jooyandeh, 2009) and / or increasing the amount of butter that has intensive yellow colour.

Incorporating of whey protein hydrolysate caused a significant increase in Hardness, adhesiveness, cohesiveness and springiness values for all processed cheese spread treatments and this increase was proportional to the rate of adding whey protein hydrolysate (Table 6). On the other hand, there were negative correlation between the rate of adding whey protein hydrolysate and the values of gumminess and chewiness of 

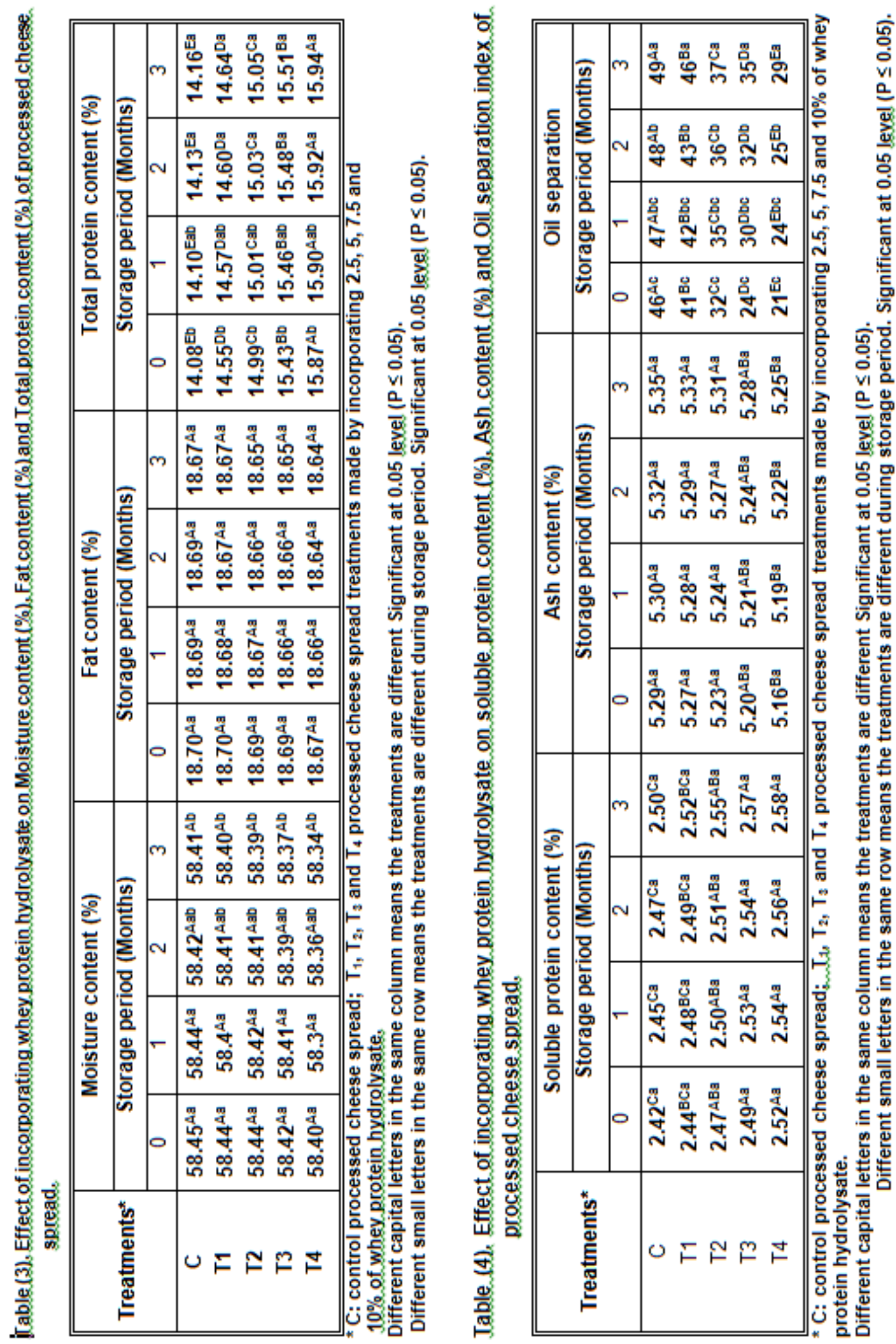
Table (5). Effect of incorporating whey protein hydrolysate on Meltability and Colour parameters of processed cheese spread.

\begin{tabular}{|c|c|c|c|c|c|c|c|c|}
\hline \multirow{3}{*}{ Treatments ${ }^{*}$} & \multirow{2}{*}{\multicolumn{4}{|c|}{$\begin{array}{c}\text { Meltability (mm) } \\
\text { Storage period (Months) }\end{array}$}} & \multirow{2}{*}{\multicolumn{4}{|c|}{ Colour parameters }} \\
\hline & & & & & & & & \\
\hline & 0 & 1 & 2 & 3 & $\mathbf{L}$ & $\mathbf{a}$ & $\mathbf{b}$ & $\Delta \mathrm{E}$ \\
\hline C & $187^{\text {Ea }}$ & $183^{\mathrm{Eb}}$ & $179^{\mathrm{Ec}}$ & $174^{\mathrm{Ed}}$ & $83.74^{A}$ & $10.50^{c}$ & $35.04^{E}$ & $0^{\mathrm{E}}$ \\
\hline T1 & $192^{\mathrm{Da}}$ & $189^{\mathrm{Db}}$ & $186^{\mathrm{Dc}}$ & $182^{\mathrm{Dd}}$ & $83.38^{B}$ & $10.54^{\mathrm{B}}$ & $35.14^{\mathrm{D}}$ & $0.375^{\mathrm{D}}$ \\
\hline T2 & $197^{\mathrm{Ca}}$ & $193^{\mathrm{Cb}}$ & $188^{\mathrm{Cc}}$ & $185^{\mathrm{Cd}}$ & $83.29^{C}$ & $10.57^{A B}$ & $35.24^{C}$ & $0.497^{\mathrm{C}}$ \\
\hline T3 & $203^{\mathrm{Ba}}$ & $200^{\mathrm{Bb}}$ & $196^{\mathrm{Bc}}$ & $192^{\mathrm{Bd}}$ & $83.10^{D}$ & $10.60^{A B}$ & $35.41^{B}$ & $0.800^{B}$ \\
\hline T4 & $205^{\mathrm{Aa}}$ & $201^{A b}$ & $198^{\mathrm{AC}}$ & $195^{\mathrm{Ad}}$ & $83.07^{\mathrm{E}}$ & $10.64^{\mathrm{A}}$ & $35.51^{A}$ & $0.830^{A}$ \\
\hline
\end{tabular}

${ }^{*} \mathrm{C}$ : control processed cheese spread; $T_{1}, T_{2}, T_{3}$ and $T_{4}$ processed cheese spread treatments made by incorporating $2.5,5,7.5$ and $10 \%$ of whey protein hydrolysate.

Different capital letters in the same column means the treatments are different Significant at 0.05 level $(P \leq 0.05)$.

Different small letters in the same row means the treatments are different during storage period. Significant at 0.05 level $(P \leq 0.05)$.

Table (6). Effect of incorporating whey protein hydrolysate on Texture profile of processed cheese spread.

\begin{tabular}{|c|c|c|c|c|c|c|}
\hline \multirow[b]{2}{*}{ Treatments* } & \multicolumn{6}{|c|}{ Texture parameters } \\
\hline & \begin{tabular}{|l} 
Hardness \\
(g)
\end{tabular} & $\begin{array}{c}\text { Adhesiveness } \\
\text { (g) }\end{array}$ & Cohesivness & \begin{tabular}{|c|} 
Springiness \\
$(\mathrm{mm})$
\end{tabular} & $\begin{array}{c}\text { Gumminess } \\
(\mathrm{N})\end{array}$ & $\begin{array}{c}\text { Chewiness } \\
(\mathrm{mJ})\end{array}$ \\
\hline C & $174^{\mathrm{E}}$ & $161^{D}$ & $0.80^{C}$ & $7.77^{D}$ & $436^{A}$ & $3889.28^{A}$ \\
\hline$T_{1}$ & $220^{\mathrm{D}}$ & $168^{C D}$ & $0.82^{B}$ & $12.89^{C}$ & $403^{B}$ & $3197.57^{B}$ \\
\hline$T_{2}$ & $240^{C}$ & $175^{\mathrm{BC}}$ & $0.83^{A B}$ & $13.81^{\mathrm{BC}}$ & $367^{c}$ & $3064.27^{C}$ \\
\hline$T_{3}$ & $264^{B}$ & $190^{A B}$ & $0.84^{\mathrm{A}}$ & $13.91^{\mathrm{AB}}$ & $246^{D}$ & $3036.55^{D}$ \\
\hline$T_{4}$ & $278^{A}$ & $218^{A}$ & $0.87^{A}$ & $13.97^{A}$ & $196^{\mathrm{E}}$ & $3012.83^{\mathrm{E}}$ \\
\hline
\end{tabular}

${ }^{*} \mathrm{C}$ : control processed cheese spread; $\mathrm{T}_{1}, \mathrm{~T}_{2}, \mathrm{~T}_{3}$ and $\mathrm{T}_{4}$ processed cheese spread treatments made by incorporating $2.5,5,7.5$ and

$10 \%$ of whey protein hydrolysate.

Different capital letters in the same column means the treatments are different. Significant at 0.05 level $(P \leq 0.05)$.

the resultant processed cheese spread treatments. These results are in accordance with those reported by Kebary et al. (1998), Badawi et al. (2001), Solowiej et al. (2012) and Lee et al. (2013).

Scores of organoleptic properties (flavour, body and texture, appearance, colour and total score) are presented in Table (7).Control processed cheese spread was not significantly $(p>0.05)$ different from $T_{1}$ and $T_{2}$ those made by incorporating 2.5 and $5.0 \%$ whey protein hydrolysate, while it was significantly different $(p \leq 0.05)$ from treatments $T_{3}$ and $\mathrm{T}_{4}$, which means that incorporating whey protein up to $5.0 \%$ did not affect significantly the quality of resultant processed cheese spread. On the other hand the scores of organoleptic properties did not change significantly during the first two months of storage period then decrease gradually up to the end of storage period (Table 7). These results are in accordance with those reported by Kebary et al. (1998), Hussein et al. (1999) and Badawi et al. (2001). 


\begin{tabular}{|c|c|c|c|c|c|c|c|c|}
\hline \multirow{20}{*}{ 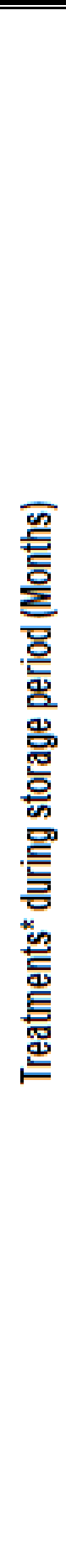 } & \multirow{4}{*}{$\vdash$} & $m$ & 品 & 莒 & 范 & 융 & 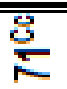 & \multirow{4}{*}{ 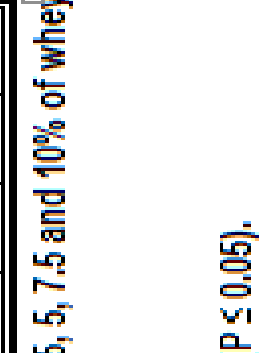 } \\
\hline & & $\sim$ & 呬 & 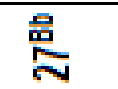 & 륫 & 总 & 范 & \\
\hline & & - & 嵒 & 啰 & : & \%్ర & 芯 & \\
\hline & & 0 & 唃 & 嵒 & మ్ర & 罗 & $\begin{array}{l} \\
\\
\stackrel{6}{\infty}\end{array}$ & \\
\hline & \multirow{4}{*}{$\stackrel{m}{\longmapsto}$} & $m$ & $\begin{array}{l}\text { 㩊 } \\
\text { 㐌 }\end{array}$ & $\begin{array}{l}\text { 畄 } \\
\text { 只 }\end{array}$ & 谷 & 吕 & $\frac{\stackrel{\mathscr{m}}{\infty}}{\infty}$ & \multirow{5}{*}{ 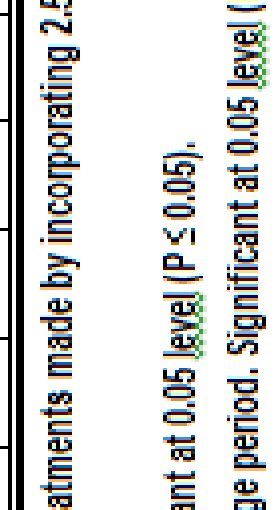 } \\
\hline & & $\sim$ & 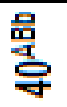 & 悤 & 㤐 & 吕 & 萝 & \\
\hline & & $\leftarrow$ & 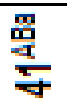 & 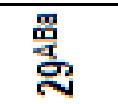 & 嵒 & 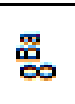 & 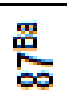 & \\
\hline & & 0 & $\stackrel{\text { 罯 }}{\underset{y}{*}}$ & 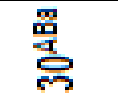 & 嵒 & 㐭 & 㽞 & \\
\hline & \multirow{4}{*}{$\stackrel{\sim}{\sim}$} & $m$ & $\begin{array}{l}\text { 导 } \\
\text { ơ }\end{array}$ & 畩 & 是 & 是 & 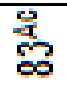 & \\
\hline & & $\sim$ & $\frac{9}{8}$ & 韋 & జి & 满 & $\frac{a}{\infty}$ & || \\
\hline & & $\leftarrow$ & 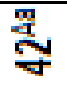 & $\frac{\operatorname{mon}}{\operatorname{m}}$ & 韋 & 睘 & 羃 & \multirow{6}{*}{ 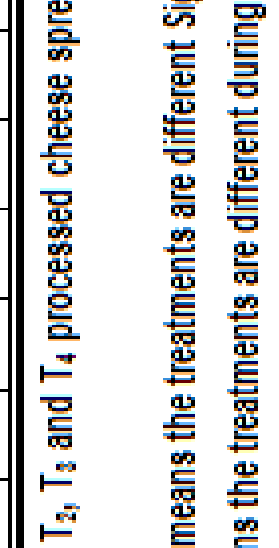 } \\
\hline & & 0 & 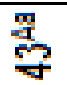 & ָั & कूँ & कूँ & 票 & \\
\hline & \multirow{4}{*}{$\vdash^{-}$} & $m$ & $\begin{array}{l}\text { 윰 } \\
\text { ? }\end{array}$ & 荧 & 芯 & 是 & $\begin{array}{l}\text { 总 } \\
\text { 峁 }\end{array}$ & \\
\hline & & $\sim$ & $\stackrel{?}{\stackrel{2}{y}}$ & $\frac{a}{m}$ & ํํㅇ & $\underset{\infty}{0}$ & ํํำ & \\
\hline & & $\leftarrow$ & 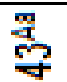 & ำ & 뭉음 & 要 & 蹗 & \\
\hline & & 0 & $\stackrel{\text { giv }}{y}$ & 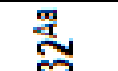 & 뭏음 & 蹗 & 罳 & \\
\hline & \multirow{4}{*}{0} & $m$ & $\frac{0}{4}$ & गั & 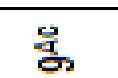 & 足 & $\frac{0}{\frac{1}{a}}$ & \multirow{5}{*}{ 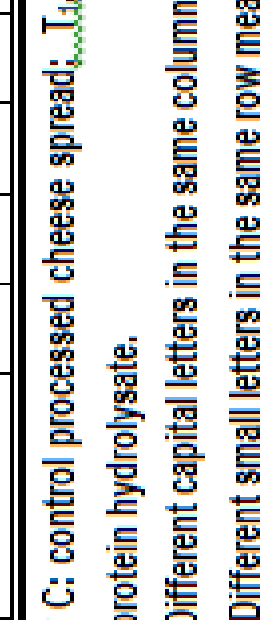 } \\
\hline & & $\sim$ & 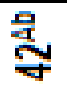 & $\frac{a}{m}$ & 웡 & 乨 & $\frac{a}{6}$ & \\
\hline & & - & 瞦 & ণ্ & 桊 & कूँ & 䍃 & \\
\hline & & 0 & 要 & 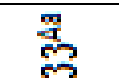 & 䋨 & 卷 & 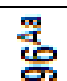 & \\
\hline \multicolumn{3}{|c|}{ 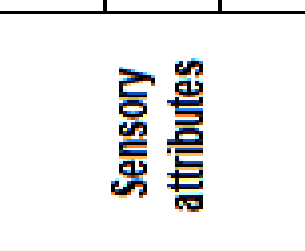 } & 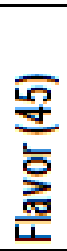 & 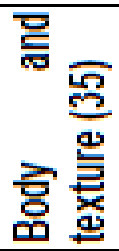 & 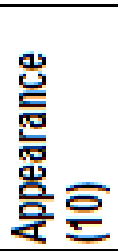 & $\begin{array}{l}\text { 을 } \\
\text { 형 } \\
\text { 항 }\end{array}$ & $\frac{\text { 응 }}{\text { 종 }}$ & \\
\hline
\end{tabular}




\section{REFERENCES}

Abdel-Baky, A. A., A. A. El-Neshawy and S. M. Farahat (1987). The use of Ras cheese made by direct acidification in the manufacture of processed cheese spread. Egypt. J. Dairy Sci., 15 (2): 273 $-285$.

Abd El-Salam, M.H., A.F. Al-Khamy, GA. El-Garawany, A. Hamed and A. Khader (1996). Composition and rheological properties of processed cheese spread as affected by the level of added whey protein concentrates and emulsifing salt. Egypt. J. Dairy Sci., 24: $309-322$.

Al-Khamy, A.F., G.A. El-Garawany, A. Khader, A. Hamed and M.H. Abd-ElSalam (1997). The use of whey protein concentrates in Processed Cheese Spreads. Egypt. J. Dairy Sci., 26: 151 159

Arla Foods Ingredients Bulletin (2016). Versatile quality processed cheese with flexible Nutrilac ${ }^{\circledR}$ solutions. www.arlafoodsingredients.com.

A.O.A.C (2010). Association of Official Analytical Chemists. Official Methods of Analysis. $17^{\text {th }}$ Ed., Washington, D.C., USA.

Badawi, R.M., M.A. El-Assar and I.I. Badran (2001). Quality of chocolate processed cheese food. Minufiya J. Agric. Res., 26: 445.

Bonczar, G., M. Wszołek and A. Siuta (2002). The effects of certain factors on the properties of yoghurt made from ewe's milk. Food Chem 79:85-91.

Business Wire (2017). Global Processed Cheese Market Report. www.businesswire.com.

El-Shibiny, S., M.M. Metwally, H.M. ElEtriby, S.M. El-Died and F.M. Assem (1996). Changes in processed cheese during storage as affected by the packaging materials. Egypt. J. Dairy Sci., 24: 197 - 206.
Egyptian Orgnization for Standards (2013). Processed cheese. Part 2: Spreadable processed cheese, Egyptian Standard (ES) 999/2005.

Foegeding, E.A., J.P. Davis, D. Doucet and M.K. McGuffey (2002). Advances in modifying and understanding whey protein functionally. Trends in Food Sci. and Technol., 13: 151 - 159.

Frokjaer, S. (1994). Use of hydrolysates for protein supplementation. Food Technol. 48: 86-88.

Gouda, A. and S. El-Shibiny (1987). The use of ultrafiltered skim milk in the manufacture of processed cheese spread. Egypt. J. Dairy Sci., 15 (2): 255 $-262$.

Guinee, T.P., M. Caric and M. Kalab (2004). Pasteurized processed cheese and substitute/imitation cheese products. In, cheese: Chemistry, Physics and Microbiology, (eds P.f. Fox, P.L.H. McSweeney, T.M. Cogan \& T.P. Guinee), $3^{\text {rd }}$ ed., Elsevier, London, 2: $349-394$.

Hamed, A., A. Khader, A.F. Al-Khamy, G.A. El-Garawany and M.H. Abd ElSalam (1997). Effect of storage on the composition rheological properties and organoleptic quality of comrnercial processed cheeses. Egypt. J. Dairy Sci., 25: 113 - 122.

Hussein, S.A., A.M. Abeid and I.I. Badran (1999). Development of new low fat processed cheese food. Annals of Agric. Sci. Moshtohor, 37 (3): 1747.

IDF (2016). The world Market for cheese 2006-2015, $11^{\text {th }}$ edition, Document No. 513, Int. Dairy Federation, Brussels.

Jooyandeh, H. (2009). Evaluation of physical and sensory properties of Iranian lavash flat bread supplemented with precipitated whey protein (PWP). African J. Food Sci., 3: $28-34$.

Kebary, K.M.K., A.M. Abeid and R.M. Badawi (1998). Impact of fat replacers 
on properties of low fat procese sed cheese spread, Proc. $7^{\text {th }}$ Egypt. Conf. of Dairy Sci. \& Technol., pp. $383-401$.

Kebary, K.M.K., S.A. Hussein and R.M. Badawi (2001). The use of whey proteins in flavoured low fat processed cheese spread $8^{\text {th }}$ Egypt. Conf. Dairy Sci. \& Technol., pp. 369 381.

Kitts, D.D. and K. Weiler (2003). Bioactive proteins and peptides from food sources. Applications of bioprocesses used in isolation and recovery. Current Pharmaceutical Design, 9: 1309 - 1323.

Ling, E.R. (1963). A Text Book of Dairy Chemistry. Vol. 2 practic $3^{\text {rd }}$ ed., Chapman and Hill Ltd. London.

Lee, S.K. and S.G. Anema (2009). The effect of the $\mathrm{pH}$ at cooking on the properties of processed cheese spreads containing whey proteins. Int. Dairy J., 115: 1373 - 1380.

Lee, S.K., M. Huss, H. Klostermeyer and S.G. Anema (2013). The effect of predenatured whey proteins on the textural and microstructural properties of model processed cheese spreads. Int. Dairy J., 32: 79 - 88.

Mayer, A. (1973). Processed cheese manufacture. $1^{\text {st }}$ ed. Food Trade Press. Ltd, London, UK.

Mihulova, M., M. Vejlupkova, J. Hanusova, J. Štetina and Z. Panovska (2013). Effect of Modified Whey Proteins on Texture and Sensory Quality of Processed Cheese. Czech J. Food Sci., 31 (6): 553 - 558.

Olson, N.F. and W.V. Price (1958). A melting test for pasteurized process spreads. J. Dairy Sci., 41: $999-1000$.

Pan, D., J. Cao, H. Guo and B. Zhao (2012). Studies on purification and the molecular mechanism of a novel ACE . Food Chem., 130: 121 - 126.

Pelegrine, D.H.G. and C.A. Gasparetto (2005). Whey proteins solubility as function of temperature and $\mathrm{pH}$. Lebensmittel-Wissenschaftund-

Technologie, 38: 77 - 80.

Perez, A.A., C. Carrera-Sánchez, J.M. Rodríguez-Patino, A.C. Rubiolo and L.G. Santiago (2012). Foaming characteristics of $\beta$-lactoglobulin as affected by enzymatic hydrolysis and polysaccharide addition: Relationships with the bulk and interfacial properties. J. Food Eng., 113: $53-60$.

Pinto, S., A.K. Rathour, J.P. Prajapati, A.H. Jana and M.J. Solanky (2007). Utilization of whey protein concentrate in processed cheese spread. Natural Product Radiance, 6 (5): 398 - 401.

Rayan, A., M. Kalab and C.A. Ernstrom (1980). Microstructure and rheology of pasteurized process cheese. Scanning Electron Microscopy, 3: 635 - 643.

Rees, R.G., W.R. Hare, G.K. Grimble, P.G. Frost and D.B. Silk (1992). Do patients with moderately impaired gastrointestinal function requiring enteral nutrition need a predigested nitrogen source? A prospective crossover controlled clinical trial., 33: 877-881.

Schmidl, M.K., S.L. Taylor and J.A. Nordlee (1994). Use of hydrolysatebased products in special medical diets. Food Technol. 48, 77-80, 85.

Smithers, G.W. (2008). Whey and whey proteins-from 'gutter-to-gold'. Int. Dairy J., 18: 695 - 704.

Steel, R.G.D. and J.H. Torrie (1980). Principles and Procedures of Statistics. A biometrical approach. $2^{\text {th }}$ Ed. McGraw- Hill Book Co., New York.

Solowiej, B. (2012). Textural, rheological and melting properties of acid reduced-fat processed and cheese analogues. Milchwissenschaft, 67: 9 13.

Sołowiej, B., P. Glibowski, S.M. Nski, J. Wydrych, A. Gawron and T.J. Nski 
(2015). The effect of fat replacement by inulin on the physicochemical properties and microstructure of acid casein processed cheese analogues with added whey protein polymers. Sci. Direct. J. 44: 1 - 11.

Thomas, M.A. (1973). The use of hard milk fat fraction in processed cheese. Australian J. Dairy Technol., 28: 77 84.

Trierum, G.V. (2002). Whey versus skimmed based calf milk replacers. Int. Dairy Topics, 1 (7): $20-21$.
Wang, X., L. Wang, X. Cheng, J. Zhou, X. Tang and X.Y. Mao (2012). Hypertension-attenuating effect of whey protein hydrolysate on spontaneously hypertensive rats. Food Chem., 134: 122 - 126.

Welderufael, F.T., T. Gibson, L. Methven and P. Jauregi (2012). Chemical characterisation and determination of sensory attributes of hydrolysates produced by enzymatic hydrolysis of whey proteins following a novel integrative process. Food Chem., 134: 1947 - 1958. 


\section{تأثثير إضافة بروتينات الثرش المتحلله على صفات مفرود الجبن المطبوخ}

خميس محمد كامل كعباري ، رجب محمد بدوي ، كمال محمد عبد الفتاح كمالي ،

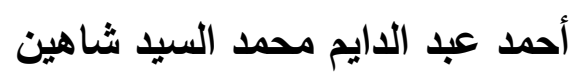

قسم علوم وتكنولوجيا الألبان ـ كلية الزراعة مديد ـ جامعة المنوفية

$$
\text { الملخص العربى }
$$

تم تصنيع خمس مُعاملات من مفرود الجبن المطبوخ وهي العينة الكنترول بالإضافة إلى أربع مُعاملات تم فيها استبدال

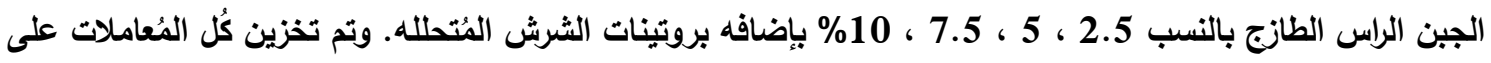

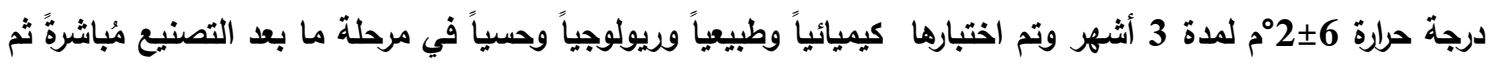

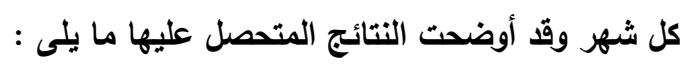

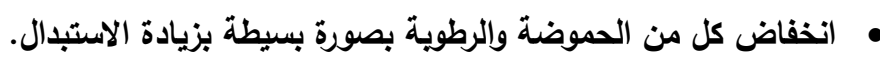

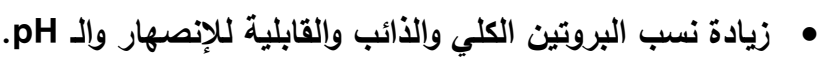

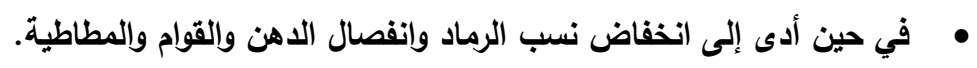

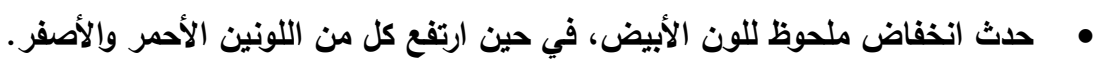

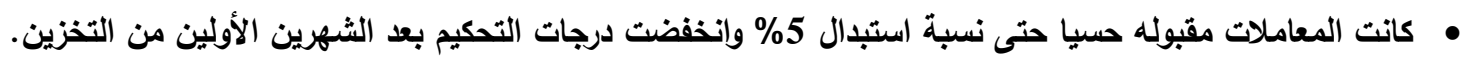

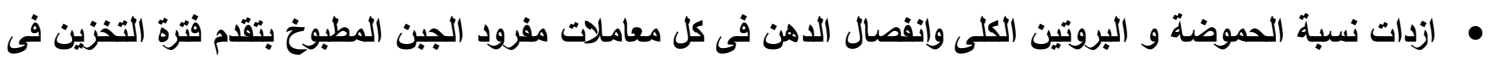
حين انخفضت قيم pH والانصهار ونسبة الرطوية.

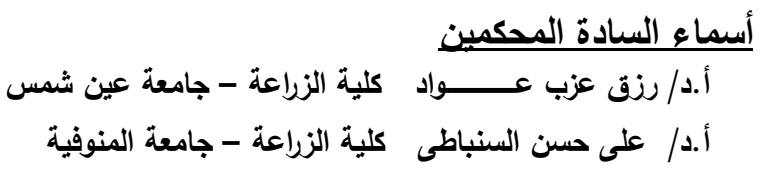


Effect of incorporating whey protein hydrolysate on processed ................... 